\title{
Peningkatan Performans Produksi Dan Kualitas Daging Pada Ayam Broiler Periode Finisher Yang Diberi Fitobiotik
}

\section{Improvement Of Production Performance And Meat Quality In Broiler Chicken Finisher Period That Given Phythobiotic}

\author{
Wardah $^{1}$, Rini Rahayu Sihmawati ${ }^{2}$ \\ ${ }^{1,2}$ Dosen Prodi Agroindustri Fakultas Vokasi Universitas 17 Agustus 1945 Surabaya \\ J1. Semolowaru No. 45 Surabaya, 60119 \\ E-mail korespondensi : wardahassery@untag-sby.ac.id
}

\begin{abstract}
Abstrak
Pemakaian fitobiotik yang dapat meningkatkan performans produksi dan kualitas daging ayam broiler terus dilakukan. Penggunaan herbal yang mengandung komponen metabolik merupakan salah satu strategi yang sangat penting. Penelitian bertujuan untuk mengevaluasi performans produksi dan kualitas daging ayam broiler yang diberi minuman fitobiotik pada periode finisher. Penelitian telah dilakukan secara eksperimental menggunakan rancangan acak lengkap dengan 4 perlakuan minuman fitobiotik 0, 30, 60, dan 90\% pada ayam broiler umur 25-40 hari dan diulang 5 kali. Fitobiotik cair yang digunakan berupa campuran dari serbuk kunyit:kencur:jahe: temulawak:daun salam dengan perbandingan 1:1:1:1:2. Hasil penelitian menunjukkan bahwa pemberian fitobiotik signifikan $(\mathrm{P}<0.05)$ meningkatkan berat badan, berat karkas dan konsumsi pakan broiler. Pemberian 30\% fitobiotik menghasilkan berat badan, berat karkas dan konsumsi pakan signifikan $(\mathrm{P}<0.05)$ lebih besar dibandingkan pemberian 0,60 dan 90\% fitobiotik. Hasil analisis kadar lemak an kolesterol daging broiler yang diberi fitobiotik signifikan $(\mathrm{P}<0.05)$ lebih rendah daripada kadar lemak daging broiler yang tidak diberi fitobiotik. Pemberian $60 \%$ fitobiotik signifikan $(\mathrm{P}<0.05)$ lebih rendah dibandingkan pemberian 0,30 dan $90 \%$ fitobiotik. Sedangkan hasil analisis kadar protein daging broiler yang diberi $60 \%$ fitobiotik signifikan $(\mathrm{P}<0.05)$ lebih tinggi dibandingkan dengan pemberian 0, 30 dan 90\% fitobiotik. Hasil penelitian ini dapat disimpulkan bahwa pemberian fitobiotik dapat mempengaruhi performans produksi dan kualitas daging ayam ayam broiler periode finisher. Pemberian 30\% fitobiotik dapat meningkatkan sebanyak $20 \%$ berat badan, berat karkas dan konsumsi pakan. Sedangkan pemberian $60 \%$ fitobiotik meningkatkan $78.58 \%$ kadar protein daging dan menurunkan sebanyak 70,54\% kadar lemak daging serta 75\% kadar kolesterol daging.
\end{abstract}

Kata kunci: Ayam broiler; finisher; produksi; kualitas daging.

\begin{abstract}
The use of phytobiotics which can improve production performance and quality of broiler chicken meat continues to be done. The use of herbs that contain metabolic components is a very important strategy. This study aims to evaluate the production performance and quality of broiler chicken meat given phytobiotic drinks in the finisher period. The study was conducted experimentally using a completely randomized design with 4 treatments of phytobiotic drinks 0, 30, 60, and 90\% in broiler chickens aged 25-40 days and repeated 5 times. The liquid phytobiotics used in the form of a mixture of Curcuma domestica powder are known as antioxidants, antimicrobials and anti-inflammatory properties. Curcuma domestica: Zingiber officinale: Kaempferia galanga: Curcuma zanthorrhiza: Syzygium polyanthum with a ratio of 1:1:1:1:2. The results showed that giving phytobiotics significantly $(P<0.05)$ increased body weight, carcass weight and broiler feed consumption. The provision of $30 \%$ phytobiotics resulted in body weight, carcass weight and feed consumption significantly ( $P$ $<0.05)$ compared to giving 0, 60 and 90\% phytobiotics. The results of the analysis of the fat and cholesterol content of broiler meat that were given phytobiotics were significantly $(P<0.05)$ lower than the fat content of broiler meat that was not given phytobiotics. The provision of $60 \%$ phytobiotics was significantly $(P<0.05)$ lower than the provision of 0, 30 and $90 \%$ phytobiotics. While the results of the analysis of protein content of broiler meat given $60 \%$ phytobiotics were significantly $(P<0.05)$ higher than those given 0,30 and $90 \%$ phytobiotics. The results of this study can be concluded that the provision of phytobiotics can affect the production performance and quality of broiler chicken meat in the finisher period. Giving 30\% phytobiotics can increase as much as $20 \%$ body weight, carcass weight and feed consumption. Meanwhile, giving $60 \%$ phytobiotics increased $78.58 \%$ of meat protein content and decreased $70.54 \%$ of meat fat and $75 \%$ of meat cholesterol.
\end{abstract}

Keywords: Broiler chicken; finisher; production; meat quality. 


\section{PENDAHULUAN}

Masyarakat modern memberikan perhatian sangat tinggi terhadap berbagai cara produksi pangan. Pangan yang berasal dari tanaman, ternak dan mikroorganisme diharapkan mempunyai kualitas yang baik, murah dan berpengaruh baik terhadap kesehatan. Masyarakat berharap peningkatan produksi pangan dunia harus tumbuh diikuti dengan peningkatan kualitas yang memadai. Pencarian berbagai komponen atau substansi yang dapat meningkatkan kinerja, efisiensi produksi, dan kualitas daging terus dilakukan.

Saat ini, peternakan unggas berkembang sangat pesat karena memiliki permintaan yang paling tinggi dibandingkan dengan jenis ternak yang lain. Tingginya permintaan pasar akan daging unggas menimbulkan lonjakan jumlah populasi ayam pedaging yang terus meningkat. Terbukti produksi daging ayam ras pedaging pada 2017 mencapai 2,14 juta ton meningkat 97 ribu ton $(4,75 \%)$ dari tahun sebelumnya hanya 2,04 juta ton, sedangkan produksi daging ayam pada tahun 2013 hanya mencapai 1,54 juta ton terus mengalami peningkatan hingga tahun 2017 (Anonymous, 2019). Prospek konsumsi produk daging broiler secara global mengalami pertumbuhan dari waktu ke waktu.Pergerakan volume konsumsi daging ayam global pada periode (20152019) berkisar antara 87232 ribu ton 94529 ribu ton (Kemendag, 2019).

Daging unggas merupakan sumber protein hewani yang baik dan dapat memberikan kontribusi yang sangat besar dalam meningkatkan konsumsi protein hewani (Madubuike et al, 2001). Namun meminimalkan pengeluaran yang tinggi untuk pakan merupakan tantangan utama. Salah satu strategi mengatasinya melalui masuknya suplemen pakan dan aditif pakan dalam makanan ayam broiler (Madubuike et al., 2001).

Penggunaan antibiotik sintetis selama ini tidak terkontrol dan menjadi perbincangan yang sangat mendasar, terutama kaitannya dengan kesehatan ternak dan manusia. Terdapat beberapa bakteri telah resisten terhadap antibiotik (Cervantes, 2012). Persoalan resistensi antibiotik ini juga dirasakan dalam bidang kesehatan hewan. Selama ini, pemanfaatan antibiotik sebagai AGP (antibiotic growth promotors) yang pemakaiannya untuk meningkatkan jumlah konsumsi pakan dan penangkal penyakit secara terus-menerus. Hal ini menyebabkan antibiotik tidak lagi dapat bertindak sebagai obat terapi pada hewan ternak, sebagian besar kajian ilmiah tersebut mengakui fakta bahwa pemberian antibiotik dengan tingkat yang rendah pada hewan penghasil pangan dapat menyebabkan pengembangan bakteri yang resisten terhadap antibiotik dan oleh karenanya ada risiko bagi manusia yang kontak dengan hewan atau mengonsumsi produknya (Cervantes, 2012).

Legalitas hukum yang mengatur penggunaan obat hewan baru keluar pada tahun 2017 dengan Peraturan Menteri Pertanian RI Nomor 14 Tahun 2017 tentang Klasifikasi Obat Hewan dimana obat antibiotik masuk dalam jajaran Obat Keras. Pemakaian antibiotik sintetis selama ini tidak rasional dan tidak mengikuti aturan yang jelas. Upaya-upaya dalam menanggulangi permasalahan tersebut adalah penggunaan bahan alam berbasis herbal yang berfungsi sebagai pengobatan bakteri. Dengan demikian, penggunaan antibiotik herbal yang selama ini digunakan pada hewan merupakan alternatif yang patut dikembangkan. Dalam kaitannya dengan obat alami sebagai pengobatan mikroba, para ahli telah mengklasifikasikan ke dalam salah satu kajian studi yaitu fitobiotik. 
Fitobiotik adalah tanaman yang mengandung senyawa kimia yang bermanfaat bagi kesehatan tubuh makhluk hidup (Sopandi et al, 2017). Selain itu, fitobiotik dapat berperan sebagai feed additive dalam formulasi pakan untuk meningkatkan produktivitas ternak (AlYahya, 1986). Produk obat alami yang berasal dari bumbu dan rempah-rempah telah digunakan sebagai bahan tambahan pakan untuk hewan ternak (Guo, 2003). Konsep pemberian tanaman sebagai bahan penyembuh telah lama ada, namun kinerjanya relatif lebih lama dibandingkan dengan obat sintetik, tetapi pada umumnya memiliki efek samping yang lebih rendah dibandingkan dengan obat sintetik (AlYahya, 1986). Pemberian herbal berasal dari tumbuhan yang mengandung serat dan senyawa metabolik untuk memperbaiki sifat pakan, pemacu kinerja produksi ternak dan kualitas produk (Sopandi et al, 2017). Jahe (Zingiber officinalis) merupakan herbal yang mengandung senyawa karminatif, diuretik, tonik dan desinfektan mengandung glukosinolat, sterol dan triterpen (Al-Yahya, 1986). Penggunaan jahe sebagai pengganti antibiotik pemacu pertumbuhan dan produktivitas unggas yang lebih tinggi, peningkatan palatabilitas pakan, pemanfaatan nutrisi, stimulasi nafsu makan, dan peningkatan aliran cairan lambung (Owen et al, 2012). Efek jahe terhadap kinerja pertumbuhan pada ayam pedaging menunjukkan bahwa penggunaan bubuk jahe dan segar jahe secara signifikan meningkatkan berat badan dan meningkatkan konversi pakan (Taylor, 2001). Jahe olahan juga juga berpengaruh signifikan terhadap kinerja pertumbuhan, efisiensi pakan, bobot badan dan bobot harian unggas (Zhang et al, 2009). Jahe juga berpengaruh signifikan terhadap kadar kolesterol ayam. Bahkan kadar kolesterol pada ayam pedaging dapat diturunkan 0,4$0,6 \%$ dengan pemberian $2,0 \%$ bubuk jahe (Zhang et al, 2009).
Daun salam

(Syzygium polyanthum) diketahui mempunyai aktivitas farmakologi antara lain sebagai antijamur, antibakteri, antimalaria, antidiare, antiinflamasi, antioksidan, antikolesterol, antidiabetes, dan antihiperurisemia (Fitriani et al, 2012). Daun salam diketahui memiliki kandungan senyawa flavonoid dan tanin yang bertindak sebagai pembersih radikal bebas (Fitriani et al, 2012). Daun salam juga mengandung senyawa steroid, fenolik, saponin, flavonoid, dan alkaloid (Liliwirianis, 2011). Senyawa utama yang terkandung di dalam daun salam adalah flavonoid. Flavonoid adalah senyawa polifenol yang memiliki manfaat sebagai antivirus, antimikroba, antialergik, antiplatelet, antiinflamasi, antitumor, dan antioksidan sebagai sistem pertahanan tubuh (Harismah dan Chusniatun, 2016). Flavonoid yang terkandung dalam daun salam yaitu kuersetin dan fluoretin (Prahastuti, et al ., 2011).

Herbal rempah-rempah jenis Curcumin mempunyai aktivitas dapat mensekresi endogen, aktivitas antimikroba, koksidiostatik, merangsang konsumsi makan, meningkatkan pertumbuhan dan respon imun (Asghari et al, 2009) diharapkan dapat menurunkan lemak dan kolesterol daging. Herbal rempah-rempah dan daun salam mempunyai aktivitas dapat mensekresi endogen, aktivitas antimikroba, koksidiostatik, diharapkan merangsang konsumsi pakan, meningkatkan pertumbuhan ternak dan respon immun serta menurunkan lemak dan kolesterol daging. Kunyit (Curcuma domestica) dikenal sebagai antioksidan, antimikroba dan antiradang. Kunyit (Curcuma domestica), jahe (Zingiber officinale), kencur (Kaempferia galanga) dan temulawak (Curcuma zanthorrhiza) mengandung minyak atsiri dari golongan monoterpen dan sesquitterpen yang dapat 
meningkatkan daya tahan tubuh, nafsu makan dan antimikroba (Jantan et al, 2012). Seperti halnya daun seligi (Phyllanthus buxifolius) telah diketahui mengandung flavonoid, tannin dan saponin yang cukup tinggi, digunakan sebagai suplemen pakan unggas dapat menurunkan kadar lemak dan kolesterol daging serta meningkatkan produksi ternak (Wardah et al, 2017). Penelitian pada unggas yang diberi perlakuan fitobiotik dari rempah-rempah dan daun salam $(S$. polyanthum) terhadap performans produksi dan kualitas daging belum pernah dilakukan.

Beberapa bahan alam berperan sebagai fitobiotik yang dapat digunakan sebagai feed additive dalam pakan atau minuman sebagai pencegahan penyakit pada ternak antar lain : temulawak, kunyit, jintan hitam, bawang putih, jahe, dan beberapa tanaman jenis lainnya. Penggunaannya dapat diberikan secara langsung atau dibuat dalam bentuk ekstraksi, dalam bentuk sediaan bubuk yang dicampurkan di dalam pakan ternak, dan pemberian sediaan cairan untuk ditambahkan pada air minum atau dicekokkan ke mulut ternak. Fitobiotik alami mampu bekerja dengan mempengaruhi sistem syaraf, metabolisme serta meningkatkan fungsi dan kekebalan tubuh. Bau dan rasa yang dihasilkan dari tanaman obat dapat mempengaruhi fungsi otak dengan menstimulasi kelenjar saliva dan sekresi cairan pencernaan pada lambung, hati, pankreas, dan usus kecil yang berguna dalam mengontrol efektivitas enzim pencernaan (Asghari et al, 2009). Lingkungan asam akan berpengaruh positif terhadap bakteri menguntungkan dan mempunyai efek toksik pada bakteri patogen. Selain itu, fitobiotik berfungsi sebagai antistress atau immunomodulator, khususnya pada ternak yang memakan zat antinutrisi, mengalami diare atau gangguan pencernaan lainnya sehingga mampu menstimulasi pencernaan pada periode akhir dan menghindari gangguan pencernaan karena efek antimicrobial (Sopandi et al, 2017).

Tanaman sebagai fitobiotik memiliki senyawa metabolit sekunder yang bermanfaat bagi tubuh ternak, bukan hanya sebagai feed additive, namun juga berfungsi secara biokimia, bioaktivitas, maupun aktivitas kimia lainnya diharapkan dapat memperlancar fungsi kerja tubuh, terutama sistem pencernaan (Wenk, 2000). Senyawasenyawa seperti : essenstial oils, alkaloid, asam, steroid, tannin, saponin, dan flavonoid serta kelompok utama lainnya telah diketahui dapat memperlancar fungsi kerja tubuh. Penggunaan fitobiotik berbasis herbal penting dilakukan dan mempunyai peluang yang besar untuk dikembangkan karena dapat membantu melengkapi nutrisi esensial, meningkatkan pertumbuhan, konsumsi pakan dan optimalisasi pemanfaatan pakan, serta berpengaruh positif terhadap karakteristik teknologi dan kualitas produk. Penggunaan fitobiotik, probiotik, prebiotik, enzim dan tanaman obat merupakan beberapa alternatif aditif dan suplemen (Wenk, 2000).

Tanaman obat juga mampu meningkatkan kecernaan zat-zat makanan yang berfungsi sebagai probiotik serta meningkatkan metabolisme nitrogen, asam amino, glukosa, dan konversi energi guna meningkatkan bobot badan dan produktivitas ternak. Tanaman obat juga berfungsi sebagai pembentuk sistem imun bagi tubuh ternak dengan cara menstimulasi sistem saraf pusat, memperbaiki dan mempertahankan permukaan epitel tubuh, meningkatkan fungsi liver dan ginjal, meningkatkan produksi sel darah putih, dan menghambat replikasi virus (Sopandi et al, 2017). Seperti halnya daun seligi ( $P$. buxifolius) telah diketahui mengandung flavonoid, tanin dan saponin yang cukup tinggi dapat menurunkan kadar lemak dan kolesterol daging serta meningkatkan produksi pada ayam broiler (Wardah et al, 2016) dan 
kualitas telur puyuh (Wardah et al, 2017). Suplemen serbuk daun seligi (P. buxifolius) pada unggas juga dapat menurunkan lemak serta kolesterol pada daging ayam broiler (Wardah et al, 2012) dan telur puyuh (Wardah et al, 2017). Pemberian sebanyak 5\% serbuk daun seligi pada pakan unggas sangat efektif meningkatkan imunitas ternak, tidak menyebabkan infeksi dan inflamasi, serta menurunkan kadar lemak dan kolesterol daging ayam broiler (Wardah et al, 2012) serta menurunkan kadar kolesterol pada telur puyuh (Wardah et al, 2017).

Sistem produksi pangan yang membutuhkan energi rendah terus dicari karena kekhawariran terhadap masalah lingkungan. masyarakat dan organisasi konsumsi lebih tertarik untuk mengkonsumsi pangan yang diproduksi secara alami (organik). Produksi pangan asal ternak juga diharapkan mengikuti tren tersebut tanpa meningkatkan beban limbah pada lingkungan (Sopandi et al, 2017). Potensi kontribusi pakan aditif dari herbal khususnya rempah-rempah dan daun salam dalam industri peternakan merupakan terobosan baru yang patut dipertimbangkan karena penggunaan aditif sintetis dalam konsentrasi yang tinggi dapat menyebabkan masalah besar secara ekologi (Wegener et al., 1999; Sopandi et al, 2017). Pengguinaan Fitobiotik herbal terhadap performans produksi, kualitas daging dan lingkungan pemeliharaan pada ayam broiler belum pernah dilakukan. Pemberian fitobiotik berbasis herbal yang dapat meningkatkan performans produksi dan kualitas daging pada ayam broiler saat panen belum pernah diberikan. Daging dengan kadar lemak dan kolesterol yang rendah merupakan dambaan konsumen. Penelitian bertujuan untuk menemukan takaran fitobiotik yang optimum dalam meningkatkan produksi dan kualitas daging ayam broiler.

\section{METODE}

Penelitian ini telah dilakukan di laboratorium Pangan Terpadu, Fakultas Vokasi Universitas 17 Agustus 1945 Surabaya, dari Bulan Juli-September 2020. Penelitian ini difokuskan untuk mengevaluasi peningkatan produksi ternak dan kualitas daging ayam broiler yang diberi minuman fitobiotik herbal. Penelitian terdiri dari 2 metode yaitu metode penelitian deskriptif analitik dan eksperimental. Penelitian eksperimental, difokuskan untuk menemukan campuran herbal terdiri dari : kunyit, Jahe, kencur, temulawak dan daun salam $(S$. polyanthum) sebagai fitobiotik yang efektif dapat meningkatkan produksi dan kualitas daging ayam broiler.

Penelitian secara eksperimental menggunakan rancangan percobaan acak lengkap 4 perlakuan proporsi fitobiotik terdiri dari : kunyit, Jahe, kencur, temulawak dan daun salam ke dalam air minum ayam broiler periode finisher yaitu : umur 25-40 hari/saat panen yang diberi pakan formula buatan pabrik dan perlakuan minuman fitobiotik dengan takaran 0,30 , 60 dan $90 \%$ dan diulang sebanyak 5 kali.

\section{Pembuatan fitobiotik}

Bahan-bahan berupa : kencur (Kaempferia galanga), jahe (Zingiber officinale), kunyit (Curcuma longa), temulawak (Curcuma xanthorrhiza) dan daun salam ( $S$. polyanthum) masingmasing dikeringkan dalam ruangan selama 3 hari, lalu digiling dan disimpan sampai akan digunakan. Selanjutnya serbuk rempah-rempah berupa kunyit:kencur:jahe:temulawak:daun salam dengan perbandingan 1:1:1:1:2 dicampur secara merata, ditambahkan sebanyak 1 liter air dan dimasak dengan suhu $70-80^{\circ} \mathrm{C}$ selama 30 menit, campuran didiamkan semalam pada suhu ruangan, lalu disaring dan disimpan. Campuran herbal diberikan sesuai dengan takaran setiap perlakuan, apabila akan digunakan ditambah sebanyak 1 liter air. 
Formula pakan yang diberikan berupa pakan pabrik dengan takaran sesuai dengan kebutuhan sedangkan minuman herbal diberikan secara ad libitum dengan takaran sebanyak 0, 30, 60 dan 90\%. Variabel kinerja produksi ayam broiler yang diamati pada penelitian ini terdiri atas konsumsi pakan, bobot badan dan bobot karkas. Variabel kualitas daging yang diamati adalah : kadar lemak, protein dan kolesterol daging. Pengamatan kinerja produksi ternak, konsumsi pakan, dan kualitas daging, dilakukan pada ternak umur 33 dan 40 hari (saat panen). Pengujian kadar lemak menggunakan metode Soxhlet dan kadar protein menggunakan metode Macro-Kjeldahl modifikasi Tecator-FOSS (AOAC., 1999). Sedangkan penentuan kadar kolesterol menggunakan metode Spektrofotometri (Boehringer, 1993)

\section{Desain Penelitian}

Penelitian ini menggunakan eksperimen Rancangan Acak Lengkap (RAL) dengan 4 perlakuan fitobiotik yaitu 0, 30, 60 dan 90\%. Sebanyak 28 ekor ayam broiler umur 20 hari dibagi secara acak menjadi 4 kelompok. Setiap kelompok berisi 7 ekor ayam dipelihara dalam kandang bambu dengan ukuran $50 \times 50 \times 50 \mathrm{~cm}$. Masa adaptasi ternak dilakukan selama 5 hari sebelum ternak diberi perlakuan. Ternak diberi pakan pabrikan sesuai kebutuhan dan air minum secara ad-libitum Sebelum ternak diberi perlakuan, semua ternak ditimbang beratnya, lalu secara acak diambil sebanyak 4 ekor untuk diperiksa kondisi awal terhadap bobot badan, bobot karkas, kadar lemak, kadar protein dan kolesterol daging. Pada umur 25-40 hari ternak diberi pakan formula dari pabrik pakan ternak dan minuman fitobiotik sesuai perlakuan yaitu : 0, 30, 60 dan 90\% dari air minum.

\section{Pengumpulan data}

Pengamatan variabel produksi berupa berat badan dan konsumsi pakan dilakukan pada ayam umur 25, 33 dan 40 hari. Sedangkan pengamatan berat karkas dan kualitas daging dilakukan pada ayam umur 33 dan 40 hari. Sebanyak 5 ekor setiap perlakuan masing-masing disembelih, dipisahkan bulunya sampai bersih, dikeluarkan isi perutnya, ditimbang lalu ayam dicuci bersih. Selanjunya diambil sampel pada bagian daging dada ayam untuk analisis kualitas dagingnya. Sampel kualitas daging ayam berupa: kadar protein, kadar lemak dan kolesterol daging ayam.

\section{Analisis Data}

Semua data hasil observasi dianalisis menggunakan analisis varian satu arah sesuai dengan rancangan percobaan acak lengkap. Uji lanjut dilakukan dengan uji beda nyata jujur untuk mengetahui letak perbedaan antar perlakuan jika perlakuan berpengaruh signifikan $(\mathrm{P}<0.05)$ terhadap variabel pengamatan.

\section{HASIL DAN PEMBAHASAN Hasil Penelitian}

Hasil pengamatan pada ayam broiler umur 33 hari seperti pada Gambar 1 menunjukkan bahwa berat badan ayam yang diberi minuman fitobiotik tidak berbeda signifikan $\quad(\mathrm{P}>0.05)$ dibandingkan dengan berat badan ayam yang tidak diberi minuman fitobiotik. Namun pada pengamatan umur 40 hari, pemberian $30 \%$ fitobiotik menghasilkan berat badan yang signifikan $(\mathrm{P}<0.05)$ lebih tinggi dibandingkan dengan pemberian 0, 60 dan 90\%. Selanjutnya, berat badan ayam yang diberi pemberian $60 \%$ fitobiotik tidak berbeda signifikan $(\mathrm{P}>0.05)$ dibandingkan dengan berat badan ayam yang diberi $90 \%$ fitobiotik pada pengamatan umur 40 hari. 


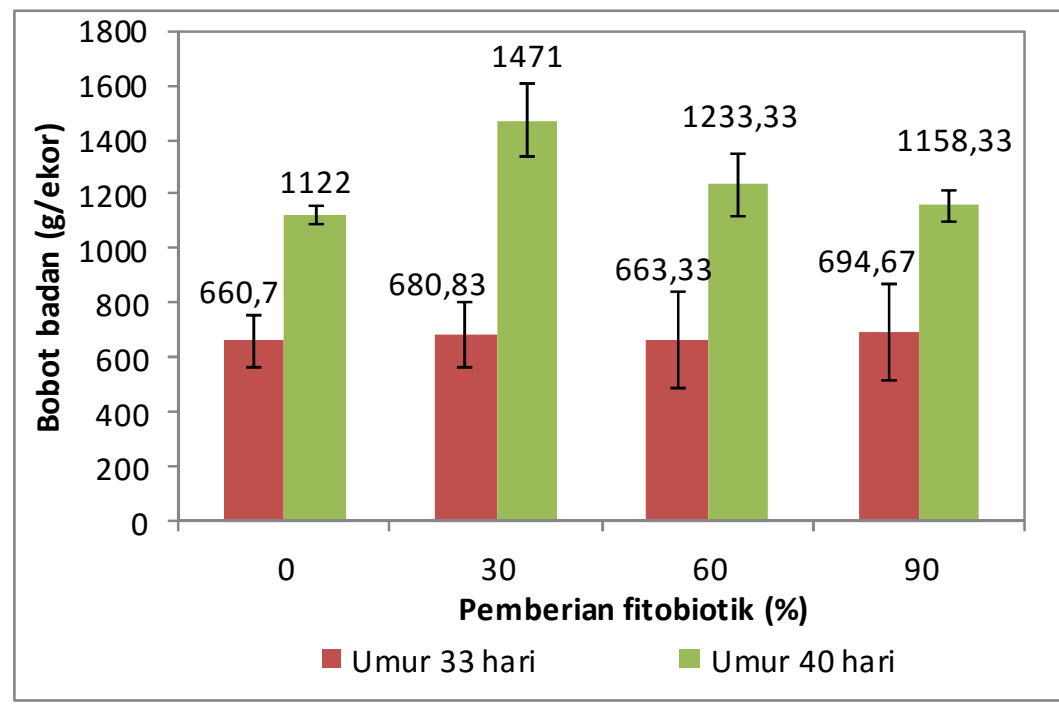

Gambar 1. Bobot badan ayam broiler periode finisher yang diberi minuman fitobiotik dengan berbagai proporsi

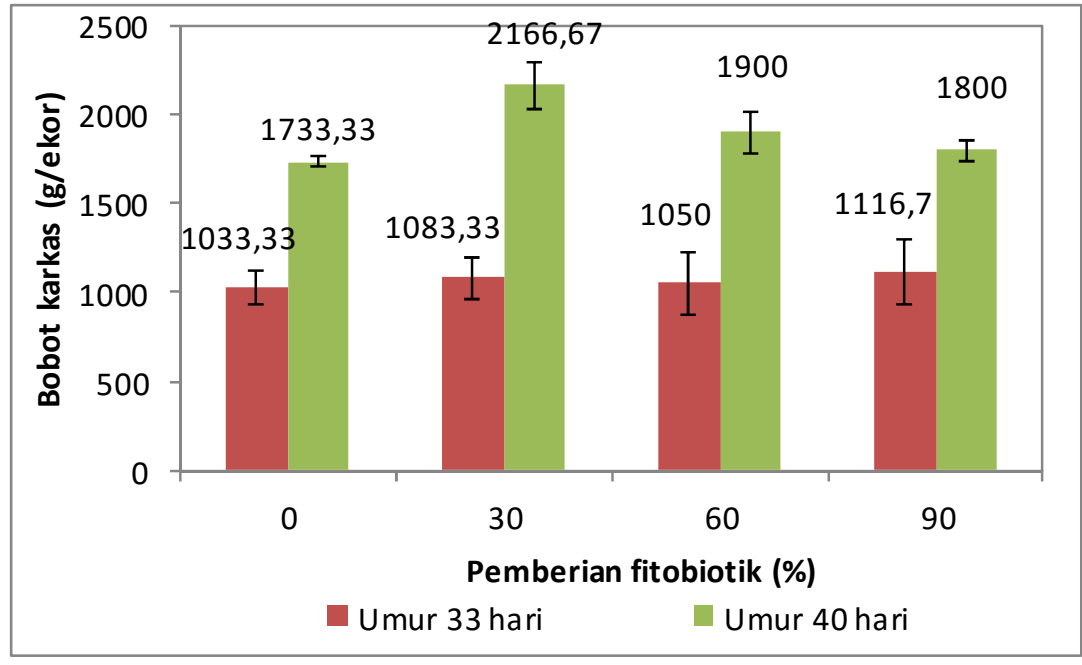

Gambar 2. Bobot karkas ayam periode finisher yang diberi minuman fitobiotik dengan berbagai proporsi

Hasil pengamatan terhadap berat karkas ayam broiler pada umur 33 hari seperti disajikan pada Gambar 2 menunjukkan bahwa ayam yang diberi minuman fitobiotik tidak berpengaruh signifikan $(\mathrm{P}>0.05)$ dibandingkan dengan ayam yang tidak diberi fitobiotik. Namun pada pengamatan umur 40 hari, pemberian $30 \%$ fitobiotik menghasilkan berat karkas signifikan $(\mathrm{P}<0.05)$ lebih tinggi dibandingkan dengan berat karkas yang diberi 0,60 dan 90\%. Sedangkan pemberian $60 \%$ fitobiotik tidak berbeda signifikan $(\mathrm{P}>0.05)$ dengan pemberian $90 \%$ fitobiotik pada pengamatan umur 40 hari. 


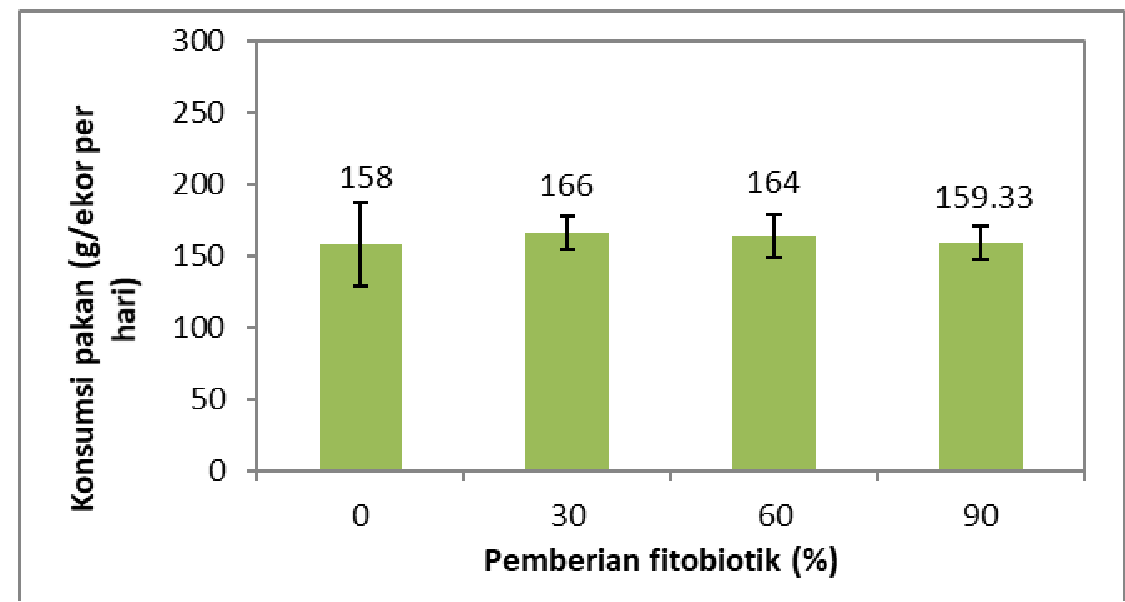

Gambar 3. Konsumsi pakan ayam broiler periode finisher yang diberi minuman fitobiotik dengan berbagai proporsi

Hasil pengamatan terhadap konsumsi pakan pada ayam broiler seperti pada Gambar 3 menunjukkan bahwa pemberian fitobiotik signifikan $(\mathrm{P}<0.05)$ dapat meningkatkan konsumsi pakan dibandingkan dengan konsumsi pakan ayam yang tidak diberi fitobiotik. Konsumsi ayam yang diberi $30 \%$ fitobiotik signifikan $(\mathrm{P}<0.05)$ lebih tinggi dibandingkan dengan pemberian 0 dan $90 \%$ fitobiotik. Namun konsumsi pakan ayam yang diberi $30 \%$ fitobiotik tidak berbeda signifikan $(\mathrm{P}>0.05)$ dengan konsumsi pakan pada ayam yang diberi $60 \%$ fitobiotik.

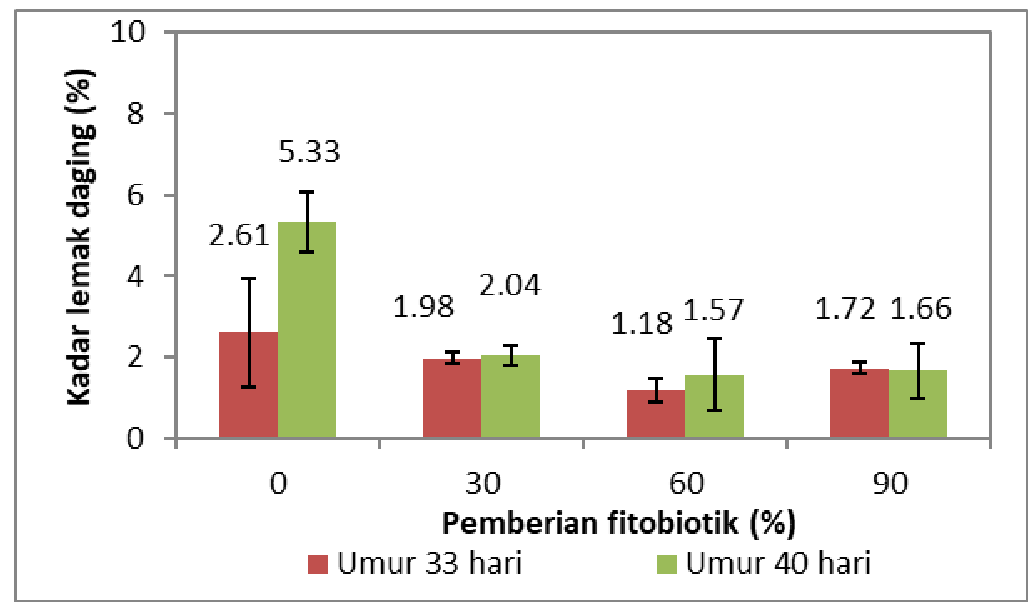

Gambar 4. Kadar lemak daging ayam broiler periode finisher yang diberi minuman fitobiotik dengan berbagai proporsi

Hasil analisis kadar lemak daging ayam broiler seperti pada Gambar 4 menunjukkan bahwa pada pengamatan umur 33 dan 40 hari menunjukkan bahwa ayam broiler yang diberi fitobiotik signifikan $\quad(\mathrm{P}<0.05) \quad$ lebih rendah dibandingkan dengan kadar lemak daging ayam broiler yang tidak diberi fitobiotik. Hasil pengamatan pada umur 33 dan 40 hari juga memperlihatkan bahwa kadar lemak daging ayam yang diberi $60 \%$ fitobiotik signifikan $(\mathrm{P}<0.05)$ lebih rendah dibandingkan dengan pemberian 0, 30 dan $90 \%$ fitobiotik. 


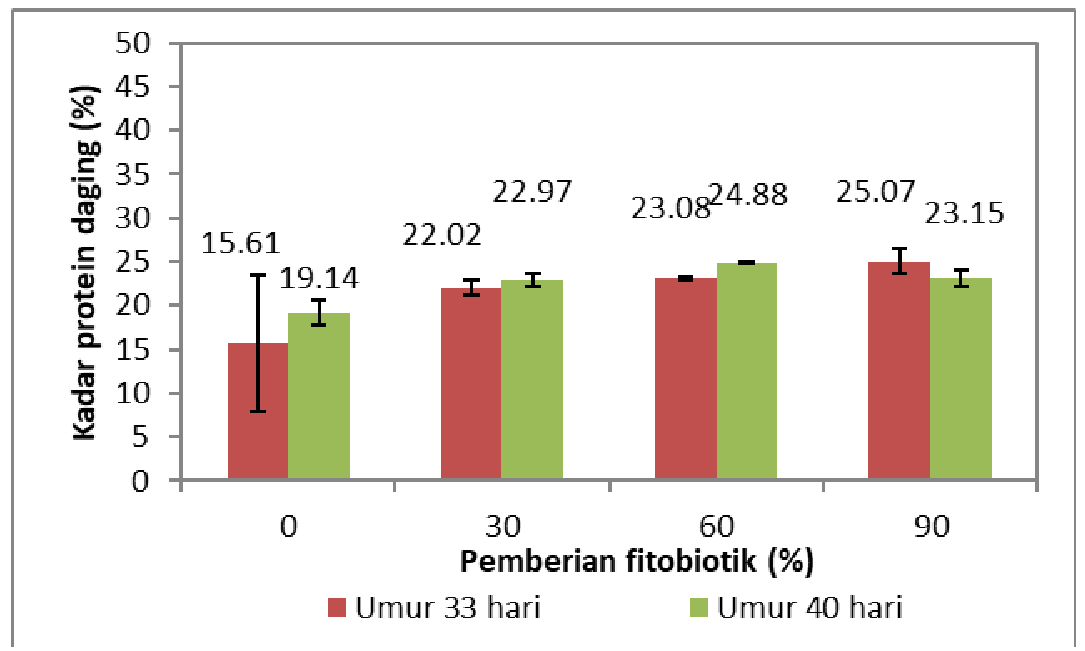

Gambar 5. Kadar protein daging ayam broiler periode finisher yang diberi minuman fitobiotik dengan berbagai proporsi

Hasil analisis kadar protein daging ayam broiler pada pengamatan umur 33 dan 40 hari seperti pada Gambar 5 menunjukkan bahwa kadar protein daging ayam yang diberi fitobiotik signifikan $(\mathrm{P}<0.05) \quad$ lebih tinggi dibandingkan dengan kadar protein daging ayam yang tidak diberi fitobiotik. Pengamatan pada umur 33 hari menunjukkan bahwa kadar protein daging ayam yang diberi $90 \%$ fitobiotik signifikan $\quad(\mathrm{P}<0.05) \quad$ lebih tinggi dibandingkan dengan pemberian 30 dan $60 \%$ fitobiotik. Namun, pengamatan pada umur 40 hari, menunjukkan bahwa kadar protein daging ayam yang diberi $60 \%$ fitobiotik signifikan $(\mathrm{P}<0.05)$ lebih tinggi dibandingkan dengan pemberian 0,30 dan $90 \%$ fitobiotik.

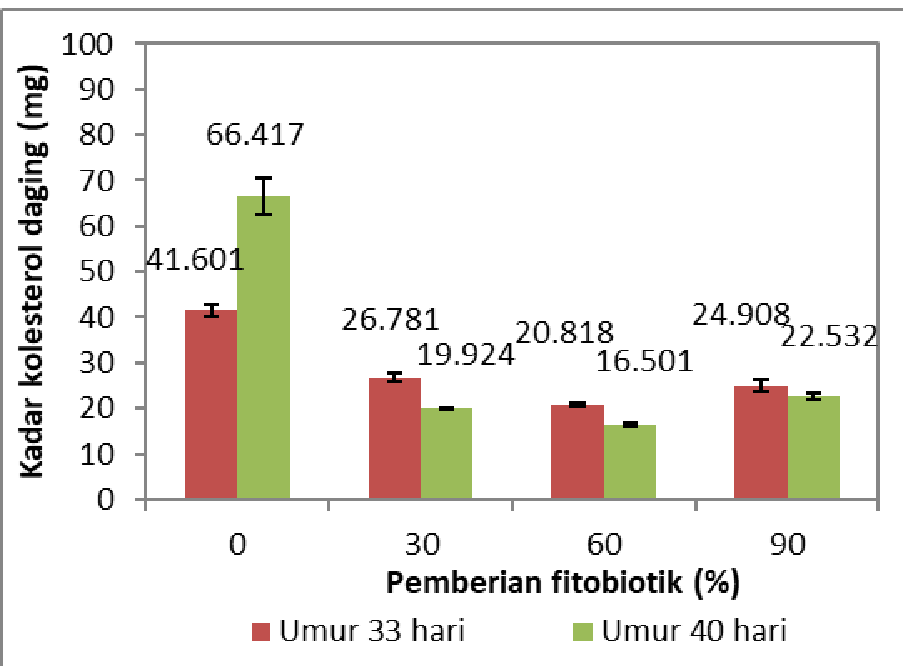

Gambar 6. Kadar kolesterol daging ayam broiler periode finisher yang diberi minuman fitobiotik dengan berbagai proporsi

Hasil analisis kadar kolesterol daging ayam broiler pada pengamatan umur 33 dan 40 hari menunjukkan bahwa kadar kolesterol daging ayam broiler yang diberi fitobiotik signifikan $(\mathrm{P}<0.05)$ lebih rendah dibandingkan kadar kolesterol daging ayam yang tidak diberi fitobiotik. Kadar kolesterol daging ayam 
pada umur 33 hari dengan pemberian $30 \%$ fitobiotik tidak berbeda signifikan $(\mathrm{P}<0.05)$ dibandingkan dengan pemberian $90 \%$ fitobiotik. Namun pada pengamatan umur 33 dan 40 hari, kadar kolesterol daging ayam yang diberi $60 \%$ fitobiotik signifikan $(\mathrm{P}<0.05) \quad$ lebih rendah dibandingkan dengan pemberian 0, 30 dan $90 \%$.

\section{Pembahasan}

Produksi suplemen/aditif yang baik dan aman bagi ternak apabila dapat memberikan jumlah dan nutrisi tersedia cukup dalam pakan/minuman serta dapat mengurangi potensi polusi dari limbah hewan di dalam kandang. Penggunaan aditif dan suplemen telah digunakan secara luas di dunia untuk berbagai tujuan termasuk membantu melengkapi nutrisi esensial, meningkatkan pertumbuhan, konsumsi pakan dan optimalisasi pemanfaatan pakan, serta berpengaruh positif terhadap karakteristik teknologi dan kualitas produk.

Tingginya performans produksi dan kualitas daging pada ayam broiler yang diberi perlakuan minuman fitobiotik hasil penelitian ini menunjukkan bahwa peran fitobiotik sangat penting. Kandungan senyawa kimia pada minuman fitobiotik, selain bermanfaat bagi kesehatan ternak, dapat meningkatkan produktivitas ternak dan kualitas daging. Meningkatnya konsumsi pakan, berat badan dan berat karkas kemungkinan karena aktivitas farmakologi dari rempah-rempah yang dapat meningkatkan konsumsi pakan sehingga berat badan dan berat karkas ayam meningkat.

Penggunaan jahe sebagai pemacu pertumbuhan untuk produktivitas unggas yang lebih tinggi, peningkatan palatabilitas pakan, pemanfaatan nutrisi, stimulasi nafsu makan, peningkatan aliran cairan lambung (Owen dan Amakiri, 2012). Efek jahe terhadap kinerja pertumbuhan pada ayam pedaging menunjukkan bahwa penggunaan bubuk jahe dan jahe secara signifikan meningkatkan berat badan dan meningkatkan konversi pakan dibandingkan dengan unggas yang diberi pakan kontrol (Taylor, 2001). Pengaruh jahe olahan terhadap kinerja pertumbuhan juga menunjukkan bahwa aditif jahe berpengaruh signifikan terhadap efisiensi pakan, bobot badan dan bobot harian (Zhang et al, 2009). Pertambahan berat badan unggas yang diberi suplemen jahe lebih tinggi dibandingkan kelompok kontrol (Zhang et al, 2009).

Menurunnya konsumsi pakan pada ayam yang diberi $90 \%$ fitobiotik kemungkinan adanya kandungan saponin pada daun salam. Hal ini mengakibatkan turunnya berat badan diikuti oleh menurunnya berat karkas. Saponin diduga dapat menyebabkan turunnya pertumbuhan dengan menurunkan konsumsi ransum. saponin dari teh daun salam dapat menghambat pertumbuhan karena menurunkan konsumsi ransum (Ueda et al, 2004). Penurunan konsumsi ransum ini diduga disebabkan oleh penundaan laju pengosongan tembolok yang dikarenakan adanya saponin. Tidak optimalnya penyerapan zat-zat nutrisi pada saluran pencernaan mengakibatkan nilai konversi ransum ayam cukup tinggi, atau tidak efisiennya ransum yang dikonsumsi ternak (Ueda et al, 2004).. Konversi ransum dipengaruhi oleh penyakit, kualitas ransum, dan manajemen pemeliharaan (North et al, 1990).

Tingginya protein pada hasil penelitian ini kemungkinan juga karena adanya rimpang kencur (Kaempferia galanga). Kencur yang merupakan famili Zingiberaceae mengandung beberapa alkaloid, pati, protein, asam amino, mineral dan lemak (Wong et al 1992). Kencur juga mempunyai sifat farmakologi sebagai kardiotonik, antikanker, antihipertensi dan aktivitas larvasida (Xue et al, 2002). Aktivitas antioksidan pada rimpang, kencur mengandung $2,5-4 \%$ minyak atsiri 
(Ravindran et al, 2004). Demikian pula jenis Curcumin, mempunyai aktivitas dapat mensekresi endogen, aktivitas antimikroba, koksidiostatik, merangsang konsumsi makan, meningkatkan pertumbuhan dan respon imun (Asghari et al, 2009). Pemberian kunyit terhadap kinerja ayam broiler juga menunjukkan pertambahan berat badan, berat karkas dan konversi pakan secara signifikan dibandingkan dengan ayam yang tidak diberi perlakuan (Al-Sultan, 2003). Pertambahan berat badan lebih tinggi $(1344,5 \mathrm{~g})$ pada pemberian $0.5 \%$ kunyit, sedangkan ayam kontrol hanya mencapai 1268.2g. Implikasi dari perbedaan tingkat inklusi diet $(0,25,0,5$ dan $1,0 \%)$ kunyit terhadap berat badan pertambahan bobot badan, konversi pakan dan karkas ayam broiler (Al-Sultan, 2003). Kadar kolesterol ayam pedaging juga mengalami penurunan sampai $0,4-0,6 \%$ yang diberi $2,0 \%$ bubuk jahe (Zhang et al, 2009). Pemberian ekstraksi etanol temulawak (Curcuma xanthorrhiza) dapat mampu meningkatkan pertambahan bobot badan, efisiensi ransum dan menurunkan nilai konversi ransum, tidak mempengaruhi gambaran fisiologis darah namun dapat menurunkan kadar kolesterol total, trigliserida, HDL, dan LDL pada serum darah (Candra et al, 2014). Hasil penelitian menunjukkan bahwa ekstrak etanol temulawak mampu menurunkan kadar kolesterol dengan nilai terendah 60,5 dibandingkan temulawak ekstraksi air dan kontrol (Candra et al, 2014).

Daun salam ( $S$. polyanthum) adalah salah satu antimikroba alami yang mengandung minyak atsiri, tanin dan flavonoid. Penambahan tepung daun salam dalam ransum terhadap bobot badan, persentase karkas, potongan komersial karkas dan kolesterol karkas ayam pedaging menunjukkan bahwa perlakuan pakan tidak signifikan meningkatkan bobot badan, persentase karkas, dan persentase potongan karkas tetapi secara signifikan perlakuan ini menurunkan kadar kolesterol karkas (Suhartati et al, 2008).

Menurunnya kadar lemak dan kolesterol daging ayam pada hasil penelitian ini kemungkinan karena aktivitas farmakologi dari rempah-rempah dan daun salam. Adanya komponen metabolik sekunder dalam campuran rempah-rempah dan daun salam sebagai minuman fitobiotik, sehingga dapat meningkatkan kadar protein tetapi menurunkan kadar lemak dan kolesterok daging ayam broiler. Tepung daun salam dapat menggantikan penggunaan antibiotik dalam ransum ayam broiler dan menurunkan kolesterol karkas (Anggorodi, 1994). Selain berpotensi sebagai antibakteri, daun salam juga mengandung tanin, saponin dan serat yang cukup tinggi (Anggorodi, 1994). Komponen ini dapat dimanfaatkan untuk menghambat penimbunan lemak dan kolesterol dalam tubuh ternak sehingga dapat meningkatkan kualitas karkas dan menurunkan kolesterol karkas ayam broiler (Anggorodi, 1994). Hasil analisis kimia terhadap campuran rempah-rempah dan daun salam yang digunakan dalam penelitian terbukti mengandung tanin yang cukup tinggi yaitu sebesar $4,3 \%$. Tingginya kandungan tannin dalan herbal ini kemungkinan dapat menurunkan kolesterol daging.

Kunyit juga berperan dalam penurunan kadar lemak. Hasil penelitian juga menunjukkan bahwa terjadi penurunan persentase lemak sebesar $1,0 \%$ pada daging ayam yang diberi $1,0 \%$ kunyit dalam ransum ayam broiler (Al-Sultan, 2003). Hasil tes organoleptik terungkap juga bahwa pemberian 1,0\% kunyit pada ransum pakan broiler tidak menyebabkan rasa, warna dan bau yang tidak normal. Bahkan dapat meningkatkan jumlah eritrositik dan total leukositik (Al-Sultan, 2003). Pemberian $0,5 \%$ kunyit sebagai feed additive dapat meningkatkan performa keseluruhan ayam broiler (Al-Sultan, 2003). Sedangkan kadar kolesterol pada 
ayam broiler dapat diturunkan hingga $0,4-$ $0,6 \%$ dengan pemberian $1 \%$ bubuk jahe . Herawati (2010) melaporkan bahwa ayam broiler strain hubbard yang diberi $2 \%$ tambahan pakan jahe merah memiliki berat badan akhir yang signifikan lebih tinggi dibandingkan dengan pakan kontrol. Penggunaan jahe sebagai pengganti antibiotik pemacu pertumbuhan untuk produktivitas unggas yang lebih tinggi, peningkatan palatabilitas pakan, pemanfaatan nutrisi, stimulasi nafsu makan, dan peningkatan aliran cairan lambung (Owen dan Amakiri, 2012).

$$
\text { Daun salam (Syzygium }
$$

polyanthum) diketahui mempunyai aktivitas farmakologi antara lain sebagai antijamur, antibakteri, antimalaria, antidiare, antiinflamasi, antioksidan, antikolesterol, antidiabetes, dan antihiperurisemia (Fitriani et al, 2012). Daun salam diketahui memiliki kandungan senyawa flavonoid dan tanin yang bertindak sebagai pembersih radikal bebas (Fitriani et al, 2012). Selain itu daun salam juga mengandung senyawa steroid, fenolik, saponin, flavonoid, dan alkaloid (Liliwirianis, 2011). Senyawa utama yang terkandung di dalam daun salam adalah flavonoid. Flavonoid adalah senyawa polifenol yang memiliki manfaat sebagai antivirus, antimikroba, antialergik, antiplatelet, antiinflamasi, antitumor, dan antioksidan sebagai sistem pertahanan tubuh (Harismah dan Chusniatun, 2016). Flavonoid yang terkandung dalam daun salam yaitu kuersetin dan fluoretin (Prahastuti, et al ., 2011). Demikian pula herbal rempahrempah jenis Curcumin mempunyai aktivitas dapat mensekresi endogen, aktivitas antimikroba, koksidiostatik, merangsang konsumsi makan, meningkatkan pertumbuhan dan respon imun (Asghari et al, 2009) terbukti dapat menurunkan lemak dan kolesterol daging. Kunyit (Curcuma domestica) dikenal sebagai antioksidan, antimikroba dan antiradang. Kunyit (Curcuma domestica), jahe (Zingiber officinale), kencur (Kaempferia galanga) dan temulawak (Curcuma zanthorrhiza) mengandung minyak atsiri dari golongan monoterpen dan sesquitterpen yang dapat meningkatkan daya tahan tubuh, nafsu makan dan antimikroba (Jantan et al, 2012).

\section{SIMPULAN DAN SARAN}

Penelitian ini menyimpulkan bahwa pemberian fitobiotik dapat mempengaruhi performans produksi dan kualitas daging ayam broiler pada periode finisher. Pemberian $30 \%$ fitobiotik dapat meningkatkan sebanyak $20 \%$ berat badan, berat karkas dan konsumsi pakan. Sedangkan pemberian $60 \%$ fitobiotik meningkatkan sebanyak $78.58 \%$ kadar protein daging dan menurunkan sebanyak $70,54 \%$ kadar lemak daging serta sebanyak $75 \%$ kadar kolesterol daging ayam broiler .

Penelitian ini menyarankan untuk memanfaatkan $30 \%$ minuman fitobiotik yang terdiri atas. Untuk meningkatkan kinerja produksi ayam broiler. Namun demikian untuk meningkatkan kualitas daging ayam broiler, disarankan memberikan $60 \%$ fitobiotik.

\section{UCAPAN TERIMA KASIH}

Penulis mengucapkan terima kasih kepada Rektor Universitas 17 Agustus 1945 Surabaya melalui LPPM Untag Surabaya yang telah membiayai kegiatan Penelitian dengan judul "Penggunaan Fitobiotik Berbasis Herbal Terhadap Performans Produksi, Kualitas Daging dan Lingkungan Peemeliharaan pada Ayam Broiler Periode Finisher" Tahun Anggaran 2020 dengan Kontrak Penugasan No. 428.23/ST/003/LPPM/Lit/VII/2020.

Penulis juga mengucapkan terima kasih kepada kepala Lab. ULP Univ. Airlangga, Lab. Environmental Laboratory, 
Mechanical Laboratory and Calibration Mutiara Kebonagung dan Lab. Pangan Terpadu Universitas 17 Agustus 1945 Surabaya yang telah memberikan kesempatan dan waktunya dalam melakukan analisis bahan penelitian.

\section{DAFTAR PUSTAKA}

Anggorodi. 1994. Ilmu Makanan Ternak Umum. Penerbit Gramedia, Jakarta

AL-Sultan S.I. 2003. The Effect of Curcuma longa (Tumeric) on Overall Performance of Broiler Chickens. International Journal of Poultry Science 2 (5): 351-353.

Al-Yahya MA, 1986. Phytochemical studies of the plants used in traditional medicine of Saudi Arabia. Fitoterapia., 57: 179-182.

Anonymous.

2019.

https://databoks.katadata.co.id/datap ublish

Association of Offical Analytical Chemists (AOAC). 1999. Official Method of Analysis of The Association of Analytical Chemists. 17 $7^{\text {th }}$ Rev. Ed. Association of Official Analytical Chemists.United Kingdom.

Asghari G, Mostajeran A, Shebli M. 2009. Curcuminoid and essential oil component of turmeric at different stages of growth cultivated in iran. Research in Pharmaceutical Sciences. 4(1): 55-61.

Boehringer, M.D. 1993. Enzymatic Cholesterol High Performance CHOD-PAP KIT France

SA. 38240.

Candra, A.A, Dwi Desmiyeni Putri dan Zairiful. 2014. Perbaikan Penampilan Produksi Ayam Pedaging dengan Penambahan Ekstraksi Temulawak Pelarut Ethanol. Jurnal Penelitian Pertanian Terapan Vol. 14 (1): 64-69.

Cervantes H.M. 2012. The future of antibiotic growth promoters in poultry production. http:/civas.net/cms/assets/uploads/2 019/02/World-Antibiotic-

Awareness-Week. Malang

Fitriani, A., Hamdiyati, Y. dan Engriyani, R., 2012. Aktivitas Antifungi Ekstrak Etanol Daun Salam (Syzygium polyanthum (Wight) Walp.) Terhadap Pertumbuhan Jamur Candida Albicans Secara In Vitro. Biosfera, 2 (29) : 71-79.

Harismah, K. dan Chusniatun, 2016. Pemanfaatan Daun Salam (Eugenia Polyantha) Sebagai Obat Herbal Dan Rempah Penyedap Makanan. Warta Lpm , Pp. Vol .19 (2) : 110118.

Hart, K. J., D. R. Yãnez-Ruiz, S. M. Duval, N. R. McEwan and C. J. Newbold. 2008. Plant extracts to manipulate rumen fermentation. Anim. Feed Sci. Technol. 147:8-35.

Herawati O, 2010. The effect of red ginger as phytobiotic on body weight gain, feed conversion and internal organs condition of broiler. Int. J. Poult. Sci., 9: 963-967.

Jantan I, Saputri FC, Qaisar MN, Buang F. 2012. Correlation between chemical composition of Curcuma domestica and Curcuma xanthorrhiza and their antioxidant effect on human owdensity lipoprotein oxidation. Evidence-Based Complementary and Alternative Medicine. 1-10.

Kemendag. 2019. Analisis Outlook Pangan http://bppp.kemendag.go.id

Kemenkes, RI., 2011. 100. Top Tanaman Obat. Jakarta: Kementrian Kesehatan RI.

Liliwirianis, et al . 2011. Preliminary Studies On Phytochemical Screening Of Ulam And Fruit From Malaysia. E Journal Of Chemistry, Volume VIII.

Lovett, D. K., L. J. Stack, S. Lovell, J. Callan, B. Flynn, M. Hawkins and F.P. O'Mara. 2005. Manipulating enteric methane emissions and 
animal performance of late-lactation dairy cows through concentrate supplementation at pasture. J. Dairy Sci. 88:2836-2842.

Makkar, H. P. S. 2005. In vitro gas methods for evaluation of feeds containing phytochemicals. Anim. Feed. Sci. Technol. 123:291-302.

Mwenya, B., B. Santoso, C. Sar, Y. Gamo, T. Kobayashi, I. Arai and J. Takahashi. 2004. Effects of including 1-4 galactooligosaccharides, lactic acid bacteria or yeast culture on methanogenesis as well as energy and nitrogen metabolism in sheep. Anim. Feed Sci. Technol. 115:313326.

North, M.O. \& D.D. Bell. 1990. Commercial Chicken Production Manual. 4t" Edition. Chapman and Hall, New York.

Owen OJ and Amakiri, 2011. Serological and haematological profile of bitter leaf (V. Amgdalina) meal. Advances in Agri. Biotech., 1: 7781.

Patra, A. K., D. N. Kamra and N. Agarwal. 2006. Effect of plant extracts on in vitro methanogenesis, enzyme activities and fermentation of feed in rumen liquor of buffalo. Anim. Feed Sci. Technol. 128:276-291.

Pauzenga. 1991 Animal P. Inrtoduction in the 90"s in harmony with nature, A case study in the Nederlands. In biotechnology in the feed Industry. Proc. Alltech!s Seven Annual Symp. Nicholasville, Kentucky.

Prahastuti, S., Tjahjani, S. dan Hartini, E., 2011. The Effect Of Bay Leaf Infusion (Syzygium Polyanthum (Wight) Walp) To Decrease Blood Total Cholesterol Level In Dyslipidemia Model Wistar Rats. Jurnal Medika Planta, P. Vol. 1 No.4.
Ravindran PN, Balachandran I. Underutilized medicinal spices (II). Galanga (Kaempferia galanga L.). Spice India 2005; 18(1):22-35.

Ritz, C. W, B. D. Fairchild, \& M. P. Lacy. (2004). Implications of ammonias production and emissions from commercial poultry facilities: a review. J. Appl. Poult. Res.

Rohman, A dan Gandjar, I.G. (2009). Kimia Farmasi Analisis. Cetakan I. Pustaka Pelajar. Yogyakarta. Hal. 298-312, 319-321.

Statistik Peternakan dan Kesehatan Hewan, Direktorat Jenderal Peternakan dan Kesehatan Hewan. 2017Kementerian Pertanian RI. Jakarta

Sopandi, T dan Wardah. 2017. Potensi Industri Rakyat : Aditif Pakan Ternak Fungsional Berbasis Daun Seligi ( $P$. buxifolius). Industri Kerakyatan. Zifatama Jawara. Sidoarjo

S. Suharti, A. Banowati, W. Hermana dan K.G. Wiryawan. 2008. Komposisi dan Kandungan Kolesterol Karkas Ayam Broiler Diare yang Diberi Tepung Daun Salam (Syzygium polyanthum Wight) dalam Ransum. Media Peternakan, hlm. 138-145.

Svensson, I. 1990. Putting the lid on the heaps. Acid. Enviro. Magazine. 9: $11-15$

Taylor DJ, 2001. Effects of antibiotics and their alternatives. Br. Poult. Sci., 412: 67-687.

Ueda H., S. Matsumoto \& K. Tanoue. 2004. Growth response and crop emptying in chicks force-fed diets containing various saponins. Poult. Sci. 41:298-306

Wardah, T. Sopandi, E.B. Aksono H., and Kusriningrum. 2012. Reduction of Intracellular Lipid Accumulation, Serum Leptin and Cholesterol Levels in Broiler Fed Diet Supplemented with Powder Leaves 
of P. buxifolius. Asian Journal of Agric. Res. 6 (3) : 106-117.

Wardah, J. Rahmahani and T. Sopandi. 2017. Effect of Phyllanthus buxifolius Leaf as a Feed Supplement on Liver Function and Haematological Response of Quail (Coturnix coturnix japonica) Challenged with Infectious Newcastle Disease Virus. Int. J. Poult. Sci., 16 (9): 354-363, 2017.

Wardah dan Tiurma Wiliana S.P. 2019. Substitusi Butiran Kering Destilat (BKD) pada Formulasi Pakan Puyuh terhadap Kimia Feses. J. MIPA Unipa. Vol. 12 (2). Hal : 5465.

Wegener HC, FM Aarestrup, P BennerSmidt and F Bager,1999. Transfer of antibiotic resistant bacteria from animal to man. Acta. Vet. Scand. Suppl., 92: 51-57.

Wenk, C., 2000: Why all the discussion about herbs? pp. 79-96. in T.P. Lyons, ed. Proc. of
Alltech's 16th Annu. Symp., Biotechn. in the Feed Industry. Alltech Technical

Publications, Nottingham University Press, Nicholasville, KY.

Wong KC, Qng KS, Lim CL. 1992. Composition of the essential oil of rhizome of Kaempferia galanga L. Flavour and Fragrance J; 7:263-266.

Xue Y, Chen H. Study on the anticarcinogenic effect of three compounds of Kaempferia galanga L. Xei Shen Yan Jiu, 2002; 31(4):247-248, 251.

Zhang GF, ZB Yang, Y Wang, WR Yang, SZ Jiang and GS Gai, 2009. Effects of ginger root (Zingiber officinale) processed to different particle sizes on growth performance, antioxidant status, and serum metabolites of broiler chickens. Poult. Sci., 88: 2159-2166. 